\title{
Determinants of Rural Household Saving: The Case of North Shewa Zone, Amhara Regional State, Ethiopia
}

\author{
Alebachew Goshim Azeref ${ }^{1}$, Yohanes Tefera Gelagil ${ }^{2}$ \\ ${ }^{1}$ Department of Accounting and Finance, Debre Birehan University, Debre Birehan, Ethiopia \\ ${ }^{2}$ Department of Logistics and Supply Chain Management, Debre Birehan University, Debre Birehan, Ethiopia
}

Email address:

alebachewgoshim@gmail.com (A. G. Azeref),yohantef@gmail.com (Y. T. Gelagil)

To cite this article:

Alebachew Goshim Azeref, Yohanes Tefera Gelagil. Determinants of Rural Household Saving: The Case of North Shewa Zone, Amhara Regional State, Ethiopia. Journal of Investment and Management. Vol. 7, No. 5, 2018, pp. 151-156. doi: 10.11648/j.jim.20180705.13

Received: October 19, 2018; Accepted: November 7, 2018; Published: November 28, 2018

\begin{abstract}
Long-term economic growth requires capital investment - in infrastructure, education and technology, business expansion, and so forth - and the main domestic source of funds for capital investment is saving by household. In developing countries, economic fluctuations and climate risk lead to important income variations and leave the households vulnerable to severe hardship and challenges. Moreover, their social coverage is restricted and the credit and insurance markets are not well developed and civilized. The study aims at investigating the determinants of households' saving in north shewa zone of amhara region. Data of 150 respondents are drawn through field survey in 2017/18 by adopting multistage random sampling technique. Questions are asked directly from head of household about their education level, family size, age, amount of savings per year in birr, assets, income etc. Sample contains information about rural households. Ordinary Least Square method is used for estimation. Ordinary Least Square method analysis presents determinants of households' saving in the zone. Based on the result it is concluded that, total dependency rate, total income of household and family size significantly raise household savings. Education of household head, sex, household landholdings, marital status, and livestock size of the households reduce saving level of households. This study also supports existence of Life cycle hypothesis. Based on the results, study suggests that Government should provide free education materials and scholarships to the students at school, college and university levels. So that household can save more rather than spending on their education. Institutions that are involved in development projects need to increase their support to improve the business environment of the rural populations. Such decisions include improvement in the Transport and communication infrastructure. Also of importance is increased involvement of the government in services that support economic activities in the rural areas such as, electricity, water, extension services and marketing channels. Future research must be conducted which takes into account nonmonetary saving of rural households.
\end{abstract}

Keywords: Determinant, Growth, Life Cycle Hypothesis, Rural Household, Saving

\section{Introduction}

\subsection{Background of the Study}

Long-term economic growth requires capital investment in infrastructure, education and technology, business expansion, and so forth - and the main domestic source of funds for capital investment is saving by household. Development economics recognized for several decades the importance of mobilization of domestic savings for economic growth in developing countries. Thus, the positive relationship between saving and economic growth has long been an established fact in economics [1].
In developing countries, economic fluctuations and climate risk lead to important income variations and leave the households vulnerable to severe hardship and challenges. Moreover, their social coverage is restricted and the credit and insurance markets are not well developed and civilized. Thus, these countries mostly face saving allocation problems and have difficulties to develop productive investments. The serious problem confronting poor countries is high gap in savings and investment. Because of this high gap, these countries mostly faced challenges to finance investments needed for growth from their domestic saving $[12,10]$

It is also not surprise to see these countries to finance their investment in the short run partly through domestic 
government borrowings and/or foreign loan and grants but this can significantly increase debt burden and cannot be a solution in the long run for countries. Saving is among important variables for economic growth of any country. Saving is about income that is not consumed by immediately buying goods and services. Saving constitutes the basis for capital formation, investment and growth of a country. Generally savings are very imperative especially for supporting and developing agricultural productivity. The inability of rural households to save over time can significantly influence the rate and sustainability of capital accumulation and economic growth [5-8].

However, both savings and investment are not emphasized as a major variable for interventions for overall development in Africa in general and Ethiopia in Particular. This is the case mainly because of, first, most of the studies carried out in the field have focused on developed economies and unable to show the ground reality in poor developing countries especially in rural area. Second, most of these studies adopted a macroeconomic approach yet the behavior of economic units on the aggregate level may not necessarily be the same as on an individual or household level. And third, even the existing limited empirical research results in developing countries in general related to rural household savings and investment are varied and inconclusive $[6,15]$.

The saving level in Ethiopia particularly in rural areas is very low and little is known empirically about its patterns and determinants. Savings in rural Ethiopia is mainly made out of the income from agricultural activities. It is also characterized as seasonal and irregular as the cash flow through sale of agricultural product and availability of work is seasonal. This reduces their financial capacity to save or poorly respond to incentives that promote savings in the country. However, rural households do indeed save in the form of tangible assets and/or in financial forms which can be potentially utilized by savings institutions and for investments which is very essential for both households and national well being $[2,3]$.

Therefore, this study tries to analyze major determinants of savings behavior of rural households which has been less addressed in Ethiopia, with particular reference to North shewa Zone of selected woredas using microeconomic evidences.

\subsection{Statement of the Problem}

Household postpone current consumption in favor of saving, or future consumption, in response to economic incentive captured by future consumption relative to current consumption, or real interest rate. Consumption habit formation and its resistance for change might have an important role in the process. The saving behavior in national economies as well as in local level exhibits inertia and persistence over time. One of the area towards which public policies have been directed is improving the private saving rate of the economy. The rationale of the policy is that saving provides the ability for capital formation which, in turn, is essential for economic development. The fact that investment would be financed either from current or future saving of a national economy coupled with the imperfect international mobility of capital in general and to developing countries in particular, implies that improving Private saving rate is an important policy target [8].

In general households saving play an important role in the economic development of both developed and developing nations, due to its significance influence on the circular flow of income in the economy [4]. Savings are also important means of improving well-being, insuring against times of shocks, and providing a safeguard to help people cope in times of crisis [11, 14]. The sustenance of household savings increases the possibility of future investment both at the micro and macro- levels in the economy. Economic theory postulates that households' saving is the difference between households' income and consumption. Household income is aggregate income a household earns from all sources in a particular period. Consumption on the other hand, is the total amount of goods and services that is consumed by households during a particular period. Savings influence growth of the economy, as higher savings lead to capital accumulation and hence economic growth [13].

In Ethiopia, saving mobilization among rural household is low and this is evidence in inability of households' to provide for the basic needs of life during some in conivinencey in farming. Considering this problem the researchers are intended to study behavior and determinants of household savings in rural area of north Shewa zone Amhara regional state in Ethiopia. It is well known that households in North shewa zone collect their higher amount of money during the harvesting time, at the same time they spend it extravagantly.

But shortly the harvesting time over most of the households completely empty handed. The behavior of household in the allocation of economic resources is a critical factor that exerts influence on the growth path of a country. Considering this problem, it is necessary to study behavior and determinants of household savings of the Zone and suggest some policies at micro level. As a matter of fact, North shewa being front line Zone of Amhara region has been given little attention in the past by most academician, because the largest part of this Zone is rural area and inaccessible. Generally, almost no one is/are interested to analyze saving behavior in woredas of this area for number of years. That is why we have selected North Shewa Zone as our study area. Therefore this study is initiated to identify the determinants and behavior of house hold saving in the study area.

\subsection{Objective of the Study}

\subsubsection{General Objective}

The overall aim of this study is to identify the determinants and behavior of house hold saving in selected woredas of North Shewa zone.

\subsubsection{Specific Objectives}

The Specific objectives of the study are three and are the following: 
a) To identify factors that affect rural household Saving.

b) To assess rural household perception towards saving.

c) To asses pattern of formal and informal savings by the rural households

\subsection{Scope and Limitation of the Study}

The researcher believes that the findings of this study would have been more productive if it has been conducted at country or regional level. However, since the researchers are not full time researchers the time and financial constraints, it is out of the reach of the researcher to incorporate all the zones in country or in region in this study. Due to this, the paper is limited to five purposively selected woredas in North Shewa zone of Amhara regional state in Ethiopia.

\subsection{Significance of the Study}

The study of factors that determine small holder farmer's saving culture and assessing the socioeconomic background of small holder farmers in the study area is important in providing information that will enable to take effective measures by the house hold themselves and policy makers to improve saving culture of the households. If the problem is solved there is high agricultural productivity; it creates sustainable job opportunity, changing the standard of living of the people. Therefore, the outcome of the study is highly useful to identify innovative options and institutional arrangements that would serve as an input and finally for improved rural investment by the farmers. For policy makers in formulating rural investment policy particularly by farmers it is highly important.

\section{Methods}

\subsection{Data Source, Data Collection Instrument and Data Type}

This study mainly used primary data and secondary data. Primary data was collected directly from household head by using structured open and close ended questionnaire to be completed by sample respondent. The questionnaire was designed to capture all the necessary variables that are used to establish the determinants of saving in the area. Interview was also conducted with households head and officials (especially agricultural officers and woreda administrators). Secondary data was collected from the different reports, financial institutions that have relation to farmers, published and unpublished materials.

\subsection{Field Strategy}

It is important to design and follow a well-planned field procedure before the survey is going to be implemented. In this study, the following activities were carried out before the survey done. Enumerators were given clarification to avoid risks of miss interpretation of the questions to respondents during survey period without influencing the respondents' answers. A plan of action was formulated stating the number of interviews to be undertaken per day, how the interviews should be distributed over the weeks.

\subsection{Population and Sample Size Determination}

The population of the study is the total rural householder in the zone. Multi-stage sampling method will be used to select the sample because the population was geographically dispersed. First five woredas were selected purposively and then two kebeles from each woreda were selected again purposively. The researchers purposively select those woreda and kebles which are considered to be more productive in farming. Therefore based on this justification Moret and Jiru, Siyadebir and wayu, Minjar Shenkora, Mida woremo and Menzgera are woredas which are the focus of this study. Once we select the woredas based on their productivity the same purposive sampling procedures were implemented to select the two kebles from each woredas again based on the productivity of the kebele. Finally the researcher implement random sampling technique to select rural household respondants from each kebeles. Based on this a random sample of 150 householders from five woreds, 30 householders from each kebele was finally selected. Since the sampling procedure was fairly random, the samples adequately represent the targeted populations in the area of study.

\subsection{Model Specification}

The model specification for this study is based on Keynesian theory which relates household saving behavior with household income and other socio economic variables. So the general model for the study can be constructed as:-

$$
\mathrm{S}=\alpha+\beta 1 \mathrm{Y}+\mathrm{Z}+\mu \mathrm{i}
$$

$$
\begin{aligned}
& \text { Where }=S=\text { Saving } \\
& Y=\text { Income } \\
& Z=\text { other socio economic variables } \\
& \mu=\text { error term } \\
& \text { The specific model is:- }
\end{aligned}
$$

$$
\begin{gathered}
\mathrm{S}=\alpha+\mathrm{I} \beta 1+\mathrm{AG} \beta 2+\mathrm{AGS} \beta 3+\mathrm{FS} \beta 4+\mathrm{EDU} \beta 5+\mathrm{OC} \beta 6+\mathrm{SEX} \beta 7+\mathrm{M} \\
\mathrm{S} \beta 8+\mathrm{SZL} \beta 9+\mathrm{DR} \beta 10+\mathrm{LH} \beta 11_{+} \mu \mathrm{i}
\end{gathered}
$$

Where:-

$\mathrm{S}=$ Saving

$\mathrm{I}=$ Income

$\mathrm{AG}=$ Age of household head

AGS $=$ age square

$\mathrm{FS}=$ Family size

EDU $=$ Education level

$\mathrm{OC}=$ occupation

Sex $=$ sex

$\mathrm{MS}=$ marital status

$\mathrm{SZL}=$ number of livestock

$\mathrm{DR}=$ dependency ratio

$\mathrm{LH}=$ size of landholding

$\alpha=$ constant term

$\mu=$ error term dependent variable independent variables independent variables independent variables independent variables independent variables independent variables independent variables independent variables independent variables independent variables independent variables 


\section{Results and Discussion}

\subsection{Descriptive Statistics}

Descriptive statistics discusses the statistical data of one variable with a frequency distribution.

Table 1 below explains Mean, Median, Minimum, Maximum, and Standard Deviation of data series. Table interprets that average Age of household (AG) is 42.08 years, average completed years of Education (EDU) is 2.56 years, average expenditure on food item (Exf) is ETB 8120.4 per year and on nonfood items ETB 4608.9, average Family size (FSZ) are 6.30, average Size of land holdings (LH) are 0.75 hectares, average number of livestock own (SZL) are 6.03, average households saving (ASv) are 3193.08 per year and average dependency ratio per household (DR) is reasonably high 0.63 .

Mean and median values of age are almost same, age had less variability on the average and households' surveyed are on the average of same age. Family size of households and dependency ratio are also same on the average. Mean and Median values of Size of land holdings, number of livestock, Education levels are little changed, Size of land holdings, number of livestock, Education level of the household are moderately changed with little variability on the average. Total income of household, household savings, expenditure on food and non-food items have on the average more variability among households.

Minimum values of age, education, family size, total income of household, expenditure on food and non-food items in birr, land holding in hectare, size of livestock ownership, savings and dependency ratio are $26,0,2.02$, 2828, $-12120,1616,606,0.26,0$ and 0 respectively. Maximum values of age, education, family size, total income of household, expenditure on food and non-food items in birr, land holding in hectare, size of livestock ownership, savings and dependency ratio are $65.7,13.4,13.4,34340,11110$, $15150,1100,2.02,32.4$ and 0.86 respectively.

Table 1. Descriptive Statistics of Some Selected Variables $(N=150)$.

\begin{tabular}{llllll}
\hline Variable & Mean & Median & Std.Dev. & Min & Max \\
\hline AGE & 42.08 & 41.41 & 10.89 & 26 & 65.7 \\
EDU & 2.56 & 0 & 3.39 & 0 & 13.4 \\
FS & 6.3 & 5.6 & 2.46 & 2.02 & 13.4 \\
I & 16770.8 & 14705.6 & 8803.49 & 2828 & 34340 \\
ASv & 3193.08 & 2272.5 & 4613.17 & -12120 & 11110 \\
Exf & 8120.4 & 7221.5 & 4167.60 & 1616 & 15150 \\
Exnf & 4608.9 & 4040 & 2705.38 & 606 & 10100 \\
LH & 0.75 & 0.51 & 0.47 & 0.26 & 2.02 \\
SZL & 6.03 & 4.04 & 6.13 & 0 & 32.4 \\
DR & 0.63 & 0.65 & 0.17 & 0 & 0.86 \\
\hline
\end{tabular}

Source: computed by researcher using spss 16.0

Table 2. Distribution of Categorical Variables $(N=150)$.

\begin{tabular}{llll}
\hline Variable & Response & Frequency & Percent \\
\hline Sex & Female & 12 & 8 \\
& Male & 138 & 92 \\
Marital status & Single & 7 & 4.67 \\
& Married & 143 & 95.33 \\
\hline
\end{tabular}

\begin{tabular}{llll}
\hline Variable & Response & Frequency & Percent \\
\hline Main activity & On farm & 144 & 96 \\
& Off farm & 6 & 4 \\
Having saving account & Yes & 16 & 10.67 \\
& No & 134 & 89.33 \\
\hline
\end{tabular}

Source: computed by researcher using spss 16.0

It can be seen from table 2 above that 8 percent of the sampled households where female and the remaining 92 percent where male and 96 percent of the respondent mainly engaged on farming activity comparing to off farm employed who accounts 4 percent of the sample population, this shows that most of the families who lives in the sampled kebeles primarily depend on the farming as their main sources income. About 95.33 percent of the respondents were married and the remaining percent were single. It is also shown in the table 2 below that most of the households $(89.33 \%)$ of them do not have saving account in the financial institution but 10.67 percent of the respondents do have the account in commercial or other banks.

Table 3. Households Saving Outlet.

\begin{tabular}{lll}
\hline Saving with & Frequency & Percent \\
\hline Saving at home & 61 & 40.67 \\
Rural micro finance & 29 & 19.33 \\
Credit and saving association & 30 & 20 \\
Ekub & 11 & 7.33 \\
Commercial banks & 19 & 12.67 \\
Total & & 100 \\
\hline
\end{tabular}

Source: computed by researcher using spss 16.0

It is evident that from table 3 above most of the families do not exercise saving with commercial bank, only 12.67 percent of the sampled households were found to have saving account with the commercial or other banks. Off course families saves their surplus money after consumption in different form and place 40.67 percent of the respondents save their money at home which they consider it highly liquid and easily accessible without any additional cost at any time. The left over households $7.33 \%$, saved their money within Ekub. The sum of households who saved their after consumption money with Rural microfinance and Credit and saving association are constitute $39.33 \%$ of the sampled households.

\subsection{Determinants of Household Savings}

The preceding section has provided some descriptions concerning the relations between saving and household socio-economic variables. However, the weakness of the descriptive statistical analyses is that each determinant has been calculated without varying other determinants. This section analyzes the determinants of household savings behavior with ordinary list square estimation technique that takes the effects of all determinants at the same time in to account. 
Table 4. OLS Regression Result.

\begin{tabular}{|c|c|c|c|c|c|c|}
\hline $\mathbf{A S v}$ & Coef. & Std.Err & $T$ & $p>/ t /$ & $95 \%$ conf. & Interval \\
\hline I & 0.43 & 0.03 & 13.81 & $0.000^{*}$ & 0.36 & 0.487 \\
\hline $\mathrm{AG}$ & 412.94 & 174.59 & 2.39 & $0.019 * *$ & 67.72 & 758.17 \\
\hline AGS & -4.59 & 2.06 & -2.24 & $0.028 * *$ & -8.66 & -0.50 \\
\hline FS & 21.60 & 281.25 & 0.08 & 0.948 & -534.53 & 577.74 \\
\hline EDU & -135.40 & 80.58 & -1.70 & $0.096 * * *$ & -294.74 & 23.92 \\
\hline $\mathrm{OC}$ & 1466.80 & 246.96 & 6.00 & $0.000 *$ & 978.50 & 1955.15 \\
\hline SEX & -3500.64 & 1951.97 & -1.81 & $0.076 * * *$ & -7360.29 & 359.00 \\
\hline MS & -2894.24 & 920.99 & -3.17 & $0.002 *$ & -4668.63 & -1073.15 \\
\hline SZL & -274.49 & 62.10 & -4.46 & $0.000 *$ & -4715.31 & -151.67 \\
\hline DR & 7028.84 & 2968.81 & 2.39 & 0.192 & 1158.59 & 12899.10 \\
\hline LH & -2787.64 & 734.84 & -3.83 & $0.000 *$ & -4240.62 & -1334.64 \\
\hline -cons & -9008.54 & 3521.90 & -2.59 & 0.012 & -15972.41 & -2044.63 \\
\hline
\end{tabular}

$\mathrm{R} 2=0.78 ;$ Adjusted R2 $=.76 ;$ Observation $=150 ;$ Prob (F-stastic $=0.000$

Notes: * $1 \%$ significance level, $* * 5 \%$ significance level and $* * * 10 \%$ significance level

Source: survey calculation

Table 4 shows the regression estimates for determinants of savings to households. The Explanatory power of regression model is measured by R2 $(0.78)$, shows that $78 \%$ of the variations in households saving were explained by explanatory variables included in the model.

The coefficient of household annual income (I) was significant and positively related to savings. Results show that one Birr increase in income tends to raise household savings by 0.43 Birr because households' capacity to save increases with rise in income level. Marginal propensity to save (MPS) for household saving equation is 0.43 indicates that $43 \%$ portion of total income is saved per year.

The results of the study also show that household savings were affected by sex (SX). Considering the sex dummy, we conclude that women headed household save more than men members.

The age of the household is positively associated with savings and significant at 5\% in the study area. And when we see the coefficient of age square (AGS) comparing to age which is negatively related to saving and significant at $5 \%$. As age of household increases by 1 year it will result in an increment in household savings by 412.94 Birr. It is expected that, savings by the young household would be diminishing with age as they grow towards and beyond retirement age. This shows that the household lessen their savings, as they grow old. This confirms with the life cycle hypothesis of savings, which claims that a person would be expected to save up to a point and then start dissaving as he/she grows old.

Respondents demographic features such as educational status do have positive effect in the household savings but the results of this study show that this variable is negatively correlated with the dependent variable. The rationale behind such type of relationship may be their preference towards education of their children. Most household heads would like to spend more on their children's education and wish to provide better studies. In this way, they spend more and save less. One more year of education is attained by head of household, will reduce savings by 135.4 Birr per year.

Marital status (MS) is negatively and significantly correlated with the household savings (ASv).

Married household heads are less likely to be able to save. Married household heads can save less by about 2894.24 birr each year. ETB 2894.24 is basically increased expenditures due to marriage. But after marriage, his/her daily expenditures will increase; he/she has to take care of family, his/her responsibilities towards family will increase, he/she cannot save much amount of money that he was supposed to save previously.

Indirect relationship is found between size of land holdings (SLH) and household savings. The results suggest that households having more land holdings can save less than the households have less land holdings. Households with one more hectare of land can reduce savings by 2787.64 birr on the average. People having more land holdings can spent very large amount of money throughout the year. They have less capacity to save in response of more land holdings.

There is also significant negative correlation between number of live stocks (SZL) and savings. The number of livestock increased by one saving will reduce by 274.49 birr per year in average.

In general, sex, household annual income, age, occupation, number of Livestock owned, marital status, land size and education were statistically significant in determining the amount of savings by households in the study area.

\section{Conclusion}

The study analyzes determinants of household savings based on data collected from some selected woreda in north shoa zone through multistage random sampling technique in $2017 / 2018$. It is found that this study supports life cycle hypothesis. Age has positive relationship and square of age is negatively related to household savings. Education of household head, Number of livestock, size of land holdings, sex and marital status of household head are significantly and inversely affecting household savings. Total income of household, family size and Occupation have significant direct relationship with household savings. 


\section{Recommendations}

Based on the results, study suggests that Government should provide free education materials and scholarships to the students at school, college and university levels. So that household can save more rather than spending on their education. Institutions that are involved in development projects need to increase their support to improve the business environment of the rural populations. Such decisions include improvement in the Transport and communication infrastructure. Also of importance is increased involvement of the government in services that support economic activities in the rural areas such as, electricity, water, extension services and marketing channels. These will motivate households to increase their production, income and hence saving. Since this research covers monetary savings among households living in the rural north shoa zone, it may be of an interest to establish whether other households in different set-ups such as in urban areas behave the same. Even within the urban region, there exist different sub-populations with different socio economic characteristics. There is need of investigating the influence of the above factors on genuine saving. Since only monetary savings was considered within this study, it would be of interest for future research to assess households where nonmonetary income and savings form a significant part of their budget.

\section{References}

[1] Schmidt Hebbel, Klau, Steven B. Webb, and Gian Carlo Corsetti. (1992). Household Saving in Developing Countries, First Cross Country Evidence. The Word Bank Economic Review, Vol. 6, No. 3.

[2] Dejene Aredo, (2003). Informal Financial Institutions: The Economic Importance of Iddir, Iqqub, and Loans, Technological Progress in Ethiopian Agriculture, Proceedings of the National Workshop on Technological Progress in Ethiopian Agriculture; November 29-30, 2001. Economics Department, Addis Ababa University, Ethiopia.

[3] Dimova, Ralitza D. and Sen, Kunal. (2010). Is Household
Income Diversification a Means of Survival or a Means of Accumulation?

[4] Iyoha, M., Oyefusi, S., and Oriakhi, E., (2003). An introduction to modern Macroeconomics. Mindex publishing: Benin City, Nigeria.

[5] Manyama, M. M., (2007). Instilling a Culture of Savings in South Africa. An MSc Thesis Presented at Gordon Institute of Business Science, University of Pretoria, South Africa.

[6] Nga, M. T., (2007). An Investigative Analysis into the Saving Behavior of Poor Households in Developing Countries: With Specific Reference to South Africa. An MSc Thesis Presented to the Department of Economics, University of the Western Cape. South Africa.

[7] Nwachukwu, T. and P. Odigie, (2009). What Drives Private Saving in Nigeria. Centre for the Study of African Economies Conference, University of Oxford.

[8] Prinsloo, J. W., (2000). The Saving Behavior of the South African Economy. Occasional Paper No 14, South African Reserve Bank. South Africa.

[9] R. Adeyemo and A. S. Bamire. (2005). Saving and Investment Patterns of Cooperatve Farmers in Shouthwestern Nigeria.

[10] Rogg, C., (2006). Asset Portfolios in Africa Evidence from Rural Ethiopia. UNU-WIDER, Centre for the Study of African Economies, University of Oxford. Department for International Development (UK). Research Paper No. 2006/145.

[11] Rutherford, S. (1999). The poor and their money. Delhi, India: Oxford University Press Saving in the Philippines. A paper submitted to USAID/Philippines OEDG.

[12] Deaton, A. S., (2005). Franco Modigliani and the Life Cycle Theory of Consumption. Banca Nazionale del Lavoro Quarterly Review.

[13] Solow. (1956). Saving, Investment and Economic growth.

[14] [14] Zeller, M. and Sharma, M. (2000). Many borrow, more save and all insure: Implications for food and micro-finance policy. Food Pol, 25: 143-16.

[15] Zhu, Q., (2004). The Impact of Rural Enterprises on Household Savings in China. ZEF - Discussion Papers on Development Policy Bonn, Germany. 